\title{
Systematic review of pediatric health outcomes associated with childhood adversity
}

Debora Lee Oh ${ }^{1 *}$, Petra Jerman ${ }^{1}$, Sara Silvério Marques ${ }^{1}$, Kadiatou Koita ${ }^{1}$, Sukhdip Kaur Purewal Boparai ${ }^{1,2}$, Nadine Burke Harris ${ }^{1}$ and Monica Bucci ${ }^{1}$

\begin{abstract}
Background: Early detection of and intervention in childhood adversity has powerful potential to improve the health and well-being of children. A systematic review was conducted to better understand the pediatric health outcomes associated with childhood adversity.

Methods: PubMed, PsycArticles, and CINAHL were searched for relevant articles. Longitudinal studies examining various adverse childhood experiences and biological health outcomes occurring prior to age 20 were selected. Mental and behavioral health outcomes were excluded, as were physical health outcomes that were a direct result of adversity (i.e. abusive head trauma). Data were extracted and risk of bias was assessed by 2 independent reviewers.

Results: After identifying 15940 records, 35 studies were included in this review. Selected studies indicated that exposure to childhood adversity was associated with delays in cognitive development, asthma, infection, somatic complaints, and sleep disruption. Studies on household dysfunction reported an effect on weight during early childhood, and studies on maltreatment reported an effect on weight during adolescence. Maternal mental health issues were associated with elevated cortisol levels, and maltreatment was associated with blunted cortisol levels in childhood. Furthermore, exposure to childhood adversity was associated with alterations of immune and inflammatory response and stress-related accelerated telomere erosion.

Conclusion: Childhood adversity affects brain development and multiple body systems, and the physiologic manifestations can be detectable in childhood. A history of childhood adversity should be considered in the differential diagnosis of developmental delay, asthma, recurrent infections requiring hospitalization, somatic complaints, and sleep disruption. The variability in children's response to adversity suggests complex underlying mechanisms and poses a challenge in the development of uniform diagnostic guidelines. More large longitudinal studies are needed to better understand how adversity, its timing and severity, and the presence of individual genetic, epigenetic, and protective factors affects children's health and development.
\end{abstract}

Keywords: Systematic review, Childhood adversity, Pediatric health outcomes, Toxic stress, Adverse childhood experiences

\footnotetext{
* Correspondence: research@centerforyouthwellness.org

${ }^{1}$ Center for Youth Wellness, 3450 Third Street, Bldg 2, Ste 201, San Francisco,

CA 94124, USA

Full list of author information is available at the end of the article
} 


\section{Background}

Evidence has shown that adversities such as abuse or neglect experienced during childhood can have lifelong consequences by affecting the foundations of health [1-4]. This body of evidence has generated growing attention to the concept of toxic stress, the chronic or frequent activation of the stress response from exposure to serious childhood adversity in the absence of adequate support or protection from adults [5]. Through a mechanism that is influenced by genetic, social, and biological factors, exposure to childhood adversity has been linked to the dysregulation of the neuroendocrine immune circuitry, which results in alterations of brain architecture and other organ systems during sensitive periods of development [6, 7]. Negative health outcomes that follow later in life reflect the physiological, epigenetic, and cognitive consequences that the brain and body pay for adapting to stressful and traumatic experiences [2, 8].

In one of the earliest studies examining the association between cumulative childhood adversity and health outcomes, known as the Adverse Childhood Experiences (ACE) Study, Felitti et al [9] found a dose-response relationship between ACEs and many leading causes of death in adults, such as chronic respiratory disease, stroke, heart disease, cancer, and diabetes. A growing body of research has since further confirmed that childhood adversity is associated with chronic disease and early death [10-15]. Hence, early detection and intervention can have a positive, lifelong impact on an individual's health and well-being. Current efforts to address toxic stress in children are limited by gaps in understanding of the biological response to childhood adversity, and much of the existing evidence is based on adult studies with retrospective reports of adversity in childhood [15-17]. Studies on childhood adversity with pediatric health outcomes have pointed to an increased likelihood of physical and developmental health issues in children exposed to adversity [18-20], but these studies have been primarily cross-sectional, making it difficult to determine the temporal relationship between exposure and outcome. The present systematic review, therefore, was focused on longitudinal studies in children to better understand the biological mechanisms linking exposure to childhood adversity with pediatric health outcomes.

\section{Methods}

We followed the PRISMA Statement [21] in the conduct and reporting of this systematic review.

\section{Data sources}

PubMed, PsycArticles, and CINAHL were searched for the following terms in the title or abstract: "early life" OR adolescent OR child OR infant OR youth OR childhood OR prenatal OR "in utero") AND (divorce OR "parental incarceration" or "parental depression" OR abuse OR neglect OR adversity OR maltreatment OR "toxic stress" OR "allostatic load" OR "adverse childhood experience"). Other terms relevant to childhood adversity such as "trauma," "parental mental health," and "parental substance abuse" were not included as search terms because they were not specific enough to identify additional relevant articles. The searches were limited to full-text articles in the English language, published between January 1, 2001 and December 31, 2015. In addition, the searches excluded animal studies, case reports, review articles, and qualitative studies.

\section{Study selection}

Title and abstracts were reviewed and nonrelevant records (studies with no exposure to childhood adversity and/or biological health outcomes) were excluded. Exposure to childhood adversity was defined as exposure to 1 or more of the experiences shown in Table 1 , which were derived from the Center for Youth Wellness ACE Questionnaire (CYW ACE-Q) [22]. The CYW ACE-Q was designed to be administered to children aged 0-19 years and includes the traditional 10 ACEs from the ACE Study, as well as additional early life stressors identified by experts and community stakeholders. An adverse exposure in-utero (e.g. maternal drug use) was part of the original search criteria, but these studies were subsequently excluded due to conceptual differences in exposures and outcomes. Biological health outcomes were defined as objective and specific developmental or clinical changes in the health of children. Mental and behavioral health outcomes were excluded, as were direct and immediate physical effects of adverse incidents (i.e. abusive head trauma).

The first two authors (D.O. and P.J.) evaluated the full text of the retained records using eligibility criteria shown in Fig. 1. Subsequently, only records of prospective and retrospective cohort studies examining child outcomes occurring prior to the age of 20 years were retained. The retained records were further evaluated using the following inclusion criteria: 1) robust ascertainment of an ACE exposure, as defined in Table $1 ; 2$ ) robust ascertainment of a biological health outcome, excluding general measures of health, health-related quality of life, and death; 3) exposure measured prior to outcome; and 4) use of an unexposed comparison group. Each study was reviewed by the 2 authors, and disagreements were resolved through discussion. As a final step in study selection, the references of the selected studies were searched for additional studies that fit all inclusion criteria.

\section{Data extraction and synthesis}

We extracted data on setting, study design, sample size, sample description, length of follow-up, adverse exposures, 
Table 1 Adverse Childhood Experiences (ACEs), age 0-19 years

\begin{tabular}{|c|c|}
\hline Category & Definition \\
\hline \multirow[t]{3}{*}{ Abuse } & $\begin{array}{l}\text { Someone pushed, grabbed, slapped or threw something at child or child was hit so hard that she/he was } \\
\text { injured or had marks }\end{array}$ \\
\hline & $\begin{array}{l}\text { Household member swore at, insulted, humiliated, or put down child in a way that scared child or } \\
\text { household member acted in a way that made child afraid that she/he might be physically hurt }\end{array}$ \\
\hline & $\begin{array}{l}\text { Someone touched child's private parts or asked child to touch that person's private parts in a sexual way } \\
\text { that was unwanted, against child's will, or made child feel uncomfortable }\end{array}$ \\
\hline \multirow[t]{2}{*}{ Neglect } & More than once, child went without food, clothing, a place to live, or had no one to protect her/him \\
\hline & Child often felt unsupported, unloved, and/or unprotected \\
\hline \multirow[t]{5}{*}{ Household dysfunction } & Child's parents or guardians were separated or divorced \\
\hline & Child saw or heard household members hurt or threaten to hurt each other \\
\hline & Household member was depressed, mentally ill, or attempted suicide \\
\hline & Household member had a problem with drinking or using drugs \\
\hline & Household member served time in jail or prison \\
\hline \multirow[t]{9}{*}{ Other adversities } & Child was separated from primary caregiver through deportation or immigration \\
\hline & Child had a serious medical procedure or life threatening illness \\
\hline & Child experienced harassment or bullying at school \\
\hline & Child experienced verbal or physical abuse or threats from a romantic partner (i.e. boyfriend or girlfriend) \\
\hline & Child often saw or heard violence in the neighborhood or school \\
\hline & Child was detained, arrested, or incarcerated \\
\hline & Child was often treated badly because of race, sexual orientation, place of birth, disability, or religion \\
\hline & Child lived with a parent or guardian who died \\
\hline & Child was in foster care \\
\hline
\end{tabular}

The categories and definitions were derived from Center for Youth Wellness ACE Questionnaire [22], which was adapted from the original ACE Study [9]

biological health outcomes, and relevant main findings (Tables 2-3). When both simple and adjusted analyses were reported, we extracted the findings that adjusted for covariates and/or confounders. The data were narratively synthesized and organized by type of biological outcome.

\section{Bias assessment}

The first two authors (D.O. and P.J.) independently assessed the risk of selection bias, information bias, and confounding for each study using the following 6 questions adapted from Busse and Guyatt's Tool to Assess Risk of Bias in Cohort Studies [23]: 1) Was selection of exposed and nonexposed participants drawn from similar populations, 2) Was the follow-up adequate (e.g. percentage of attrition, percentage of missing data and type of missing data), 3) Can we be confident in the assessment of the exposure(s), 4) Can we be confident in the assessment of the outcome(s), 5) Did the study measure and adjust for potential confounding variables and covariates, 6) Can we be confident in the assessment of the confounding variables and covariates? The rating scale ranged from definitely yes (i.e. low risk of bias) to definitely no (i.e. high risk of bias). Rating disagreements between the 2 authors were resolved through discussion. As part of the assessment of potential confounding we also separately considered whether co-interventions were similar between the groups (i.e. social services).

\section{Results}

After removal of duplicates, 15940 records were identified. Of these, 1179 studies investigated the relationship between childhood adversities and biological health outcomes, of which 380 (32\%) reported outcomes in children. A majority of the studies with outcomes in children used a cross-sectional study design (241 studies, 63\%). We identified 97 longitudinal cohort studies in children, and 24 met our final criteria (see flow diagram in Fig. 1 for the exclusion criteria). In addition, we identified 11 studies that met all inclusion criteria from the references section of the selected studies, for a total of 35 studies (Fig. 1).

\section{Bias assessment}

The bias assessment synthesis is displayed in Fig. 2. In $77 \%$ of the studies, exposed and unexposed participants were drawn from similar populations, suggesting a low risk of bias. In regard to adequate follow-up, $68 \%$ of the studies were assessed to have a low or moderately low risk of bias. The assessments of the exposure and the outcome were rated as having a low or moderately low 


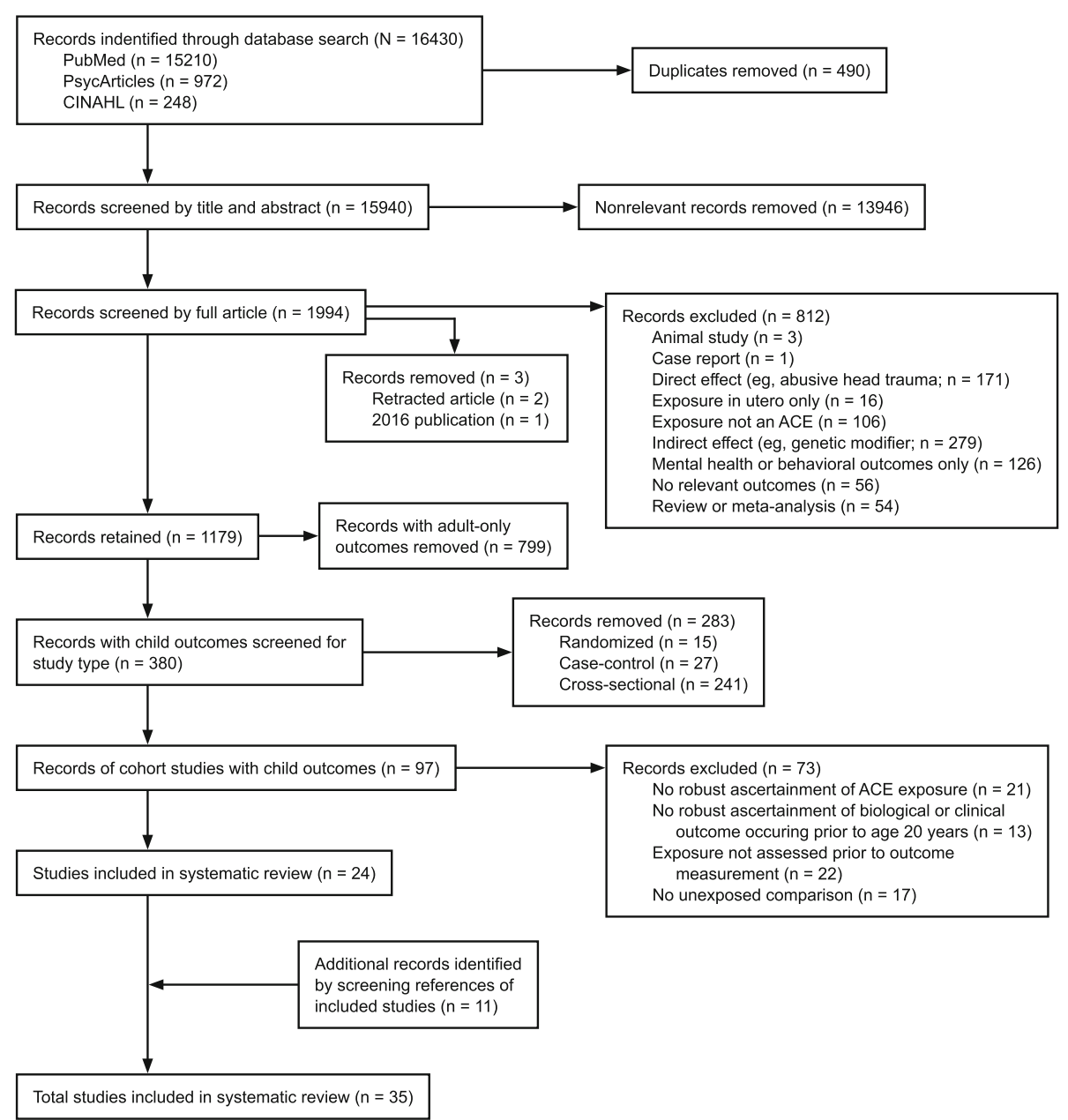

Fig. 1 Flow diagram of studies included in the systematic review

risk of bias in $94 \%$ of the studies. In regard to confounders and covariates, 92\% of the studies received a rating of low or moderately low risk of bias (Fig. 2). In addition, we observed that the majority of the studies examining maltreatment and intimate partner violence did not take into consideration the possible effect of social services for abused and neglected individuals on the outcome.

\section{Study characteristics}

Of the 35 studies published between 2001 and 2015, 20 were published in 2010 and later. Thirty-three were prospective cohort studies and 2 were retrospective cohort studies. Half of the studies were conducted in the United States, and the remaining ones were conducted in 4 other countries. Sample size ranged from 18 to 13907 participants. Six studies examined developmental outcomes (Table 2) and 29 examined clinical outcomes (Table 3).

\section{Developmental outcomes}

Six studies investigated developmental outcomes including physical, reproductive, and cognitive development. Studies found that adversity was associated with differences in height, age at menarche, and cognitive ability (Table 3).

\section{Physical and reproductive development}

Studies on physical development showed a weak association between parental divorce or separation and shorter height, but the association was not always statistically significant. Li et al found that for males whose parents divorced or separated, height was significantly lower at ages 7 and 11 years, but not at age 16 years. For females whose parents divorced or separated, height was lower on average at ages 7,11 , and 16 years, but not significantly lower [24]. Li and Power compared 2 generations of participants and found that cohort members whose parents divorced or separated were shorter on average, and offspring were taller on average, but these associations were not statistically significant [25]. Boynton-Jarrett and 
Table 2 Characteristics of included cohort studies examining the association between childhood adversity and child developmental outcomes

\begin{tabular}{|c|c|c|c|c|}
\hline $\begin{array}{l}\text { First author } \\
\text { (year, setting) }\end{array}$ & $\begin{array}{l}\text { Sample } \\
\text { description }\end{array}$ & Exposures $^{\mathrm{a}}$ & Outcomes & Findings $(95 \% \mathrm{Cl})$ \\
\hline $\begin{array}{l}\text { Boynton-Jarrett } \\
(2012, \text { UK) }[26]\end{array}$ & $\begin{array}{l}\text { Birth cohort, } \\
\text { followed to } \\
\text { age } 42 \text { years } \\
(N=4524)\end{array}$ & $\begin{array}{l}1 \text { and } 2 \text { or more forms of } \\
\text { childhood neglectful } \\
\text { environment (physical neglect, } \\
\text { maladjustment, mental } \\
\text { subnormality in the family, } \\
\text { bullying, contact with social } \\
\text { services), assessed at age } 7 \text { years } \\
\text { or at both ages } 7 \text { and } 11 \text { years }\end{array}$ & $\begin{array}{l}\text { Onset of menarche assessed at } \\
\text { age } 16 \text { years, categorized into } \\
\text { early menarche }(<=\text { age } 11 \\
\text { years), average menarche (age } \\
12-13 \text { years), and late menarche } \\
\text { (=> age } 14 \text { years) }\end{array}$ & $\begin{array}{l}1 \text { form of neglectful } \\
\text { environment, } \mathrm{OR}=1.21 \\
(1.03-1.43), \text { and } 2 \text { or more } \\
\text { forms, } \mathrm{OR}=1.76(1.41-2.20) \text {, } \\
\text { were both significantly } \\
\text { associated with late } \\
\text { menarche; neither } 1 \text { nor } 2 \text { or } \\
\text { more forms were significantly } \\
\text { associated with early } \\
\text { menarche, OR }=0.90 \\
(0.73-1.10) \text { and OR }=1.21 \\
(0.91-1.63), \text { respectively }\end{array}$ \\
\hline $\begin{array}{l}\text { Enlow }(2012, \\
\text { USA) [27] }\end{array}$ & $\begin{array}{l}\text { Birth cohort, } \\
\text { followed to } \\
\text { age } 5 \text { years } \\
(N=206)\end{array}$ & $\begin{array}{l}\text { Interpersonal trauma exposure } \\
\text { (physical abuse, psychological } \\
\text { maltreatment, neglect during } \\
\text { age } 0-24 \text { month, sexual abuse } \\
\text { during age } 24-64 \text { months, } \\
\text { witnessing partner violence } \\
\text { against the mother during age } \\
0-24 \text { or } 24-64 \text { months) }\end{array}$ & $\begin{array}{l}\text { Cognitive functioning (mental } \\
\text { and motor development, } \\
\text { intelligence) from } 24 \text { months to } \\
96 \text { month of age }\end{array}$ & $\begin{array}{l}\text { Interpersonal trauma } \\
\text { exposure during age } 0-24 \\
\text { months was significantly } \\
\text { associated with cognitive } \\
\text { scores, } P=.002 \text {; there was a } \\
\text { nonsignificant association for } \\
\text { exposure during age } 24-64 \\
\text { months, } P=.84\end{array}$ \\
\hline \multirow[t]{2}{*}{ Li (2004, UK) [24] } & $\begin{array}{l}\text { Birth cohort, } \\
\text { followed to } \\
\text { age } 33 \text { years } \\
(N=7697)\end{array}$ & $\begin{array}{l}\text { Parental separation or divorce by } \\
\text { age } 7 \text { years }\end{array}$ & $\begin{array}{l}\text { Male height SD scores at ages } 7 \text {, } \\
11 \text {, and } 16 \text { years }\end{array}$ & $\begin{array}{l}\text { Parental separation or divorce } \\
\text { was associated with lower } \\
\text { scores at ages } 7,11(p<.05) \text {, } \\
\text { and } 16 \text { years ( } P=\text { ns) }\end{array}$ \\
\hline & & $\begin{array}{l}\text { Parental separation or divorce by } \\
\text { age } 7 \text { years }\end{array}$ & $\begin{array}{l}\text { Female height SD scores at ages } \\
7,11 \text {, and } 16 \text { years }\end{array}$ & $\begin{array}{l}\text { Parental separation or divorce } \\
\text { was nonsignificantly } \\
\text { associated with lower scores } \\
\text { at ages } 7,11 \text {, and } 16 \text { years }\end{array}$ \\
\hline Li (2004, UK) [25] & $\begin{array}{l}7993 \text { birth } \\
\text { cohort } \\
\text { members, } \\
\text { followed to } \\
\text { age } 33 \text { years, } \\
\text { and } 2462 \text { of } \\
\text { their offspring }\end{array}$ & $\begin{array}{l}\text { Parental separation or divorce by } \\
\text { age } 7 \text { years }\end{array}$ & $\begin{array}{l}\text { Height SD scores at age } 7 \text { years } \\
\text { for cohort members and at age } \\
4-18 \text { years for offspring }\end{array}$ & $\begin{array}{l}\text { Parental separation or divorce } \\
\text { was nonsignificantly } \\
\text { associated with lower scores } \\
\text { for both cohort members } \\
\text { and offspring }\end{array}$ \\
\hline $\begin{array}{l}\text { Richards } \\
\text { (2004, UK) [29] }\end{array}$ & $\begin{array}{l}\text { Birth cohort, } \\
\text { followed to } \\
\text { age } 53 \text { years } \\
(N=1339)\end{array}$ & $\begin{array}{l}\text { Parental divorce or death by age } \\
8 \text { years }\end{array}$ & $\begin{array}{l}\text { Cognitive ability at ages } \\
8 \text { and } 15 \text { years }\end{array}$ & $\begin{array}{l}\text { Parental divorce or death was } \\
\text { significantly associated with } \\
\text { lower cognitive ability at } \\
\text { ages } 8, P=.05 \text {, and } 15 \text { years, } \\
P=.001\end{array}$ \\
\hline $\begin{array}{l}\text { Strathearn (2001, } \\
\text { Australia) [28] }\end{array}$ & $\begin{array}{l}\text { Birth cohort } \\
\text { (born at }<1000 \\
\text { g), followed to } \\
\text { age } 4 \text { years } \\
(N=269)\end{array}$ & $\begin{array}{l}\text { Referred or substantiated } \\
\text { maltreatment (physical, } \\
\text { emotional, sexual abuse; neglect) } \\
\text { occurring prior to cognitive } \\
\text { assessment }\end{array}$ & Cognitive delay at age 4 years & $\begin{array}{l}\text { Referrals and substantiated } \\
\text { referrals were significantly } \\
\text { associated with cognitive } \\
\text { delay, } P<.001 \text { and } P=.003 \text {, } \\
\text { respectively }\end{array}$ \\
\hline
\end{tabular}

All studies were prospective cohort studies

$95 \% \mathrm{Cl}, 95 \%$ confidence interval; OR, odds ratio; SD, standard deviation

${ }^{\mathrm{a}}$ The nonexposed comparison represents the absence of the examined exposure

Harville examined children who were raised in a neglectful environment (e.g. physical neglect, bullying) and found that 1 form of neglectful environment $(\mathrm{OR}=1.21,95 \% \mathrm{CI}$ : $1.03-1.43)$ and 2 or more forms $(\mathrm{OR}=1.76,95 \% \mathrm{CI}$ : $1.41-2.20)$ were both significantly associated with late menarche [26].

\section{Cognitive development}

The reviewed studies reported an association between early adversity and significant delays in cognitive development. Enlow et al found that interpersonal trauma exposure during age $0-24$ months, but not during age 24-64 months, was significantly associated with decreased cognitive scores at 24 to 96 months of age [27]. Similarly, Strathearn et al found a significant association between maltreatment and cognitive delay at age 4 years [28]. Richards and Wadsworth found that children who experienced parental death or divorce had lower cognitive ability scores at ages 8 and 15 years [29]. 


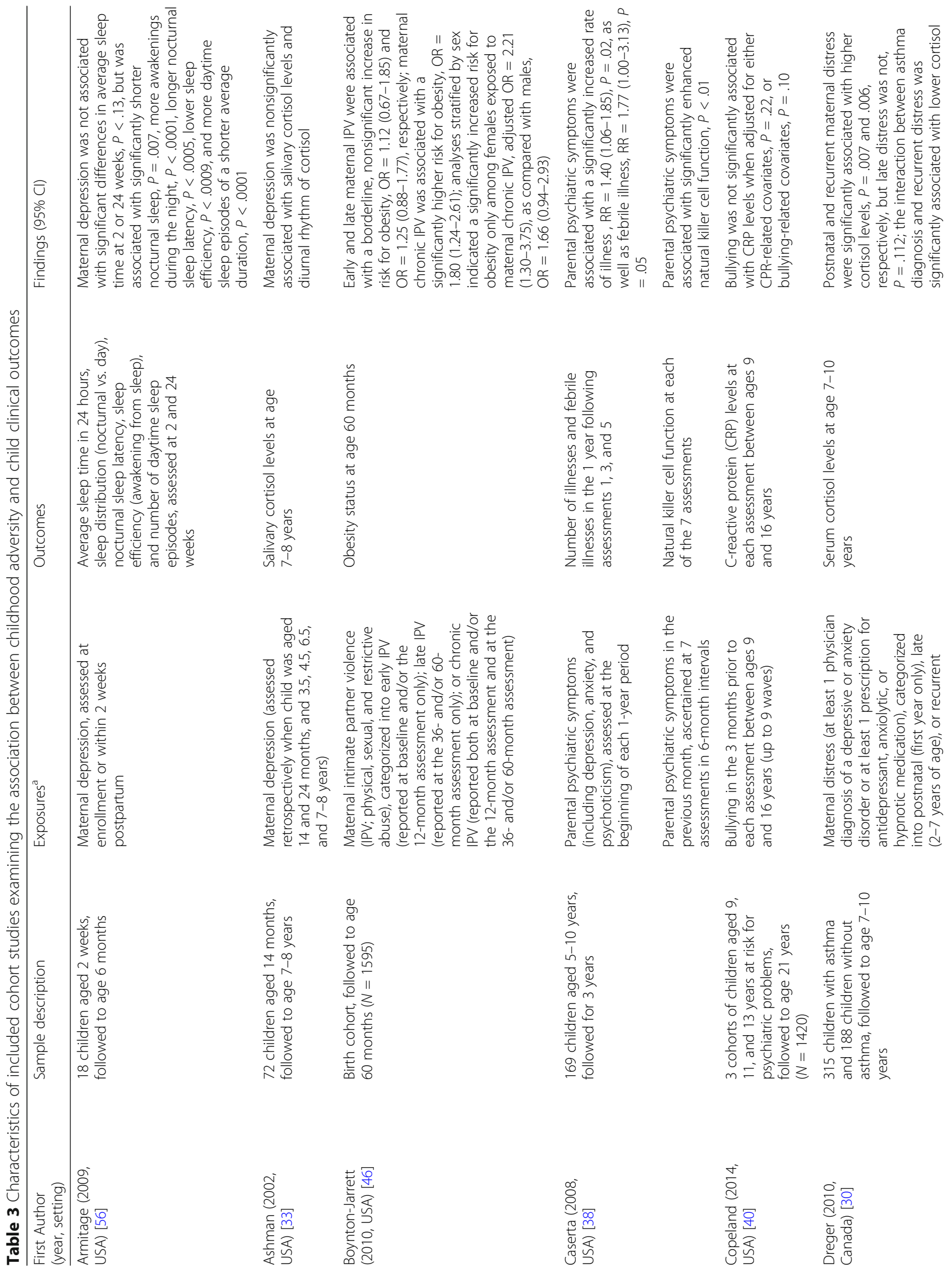




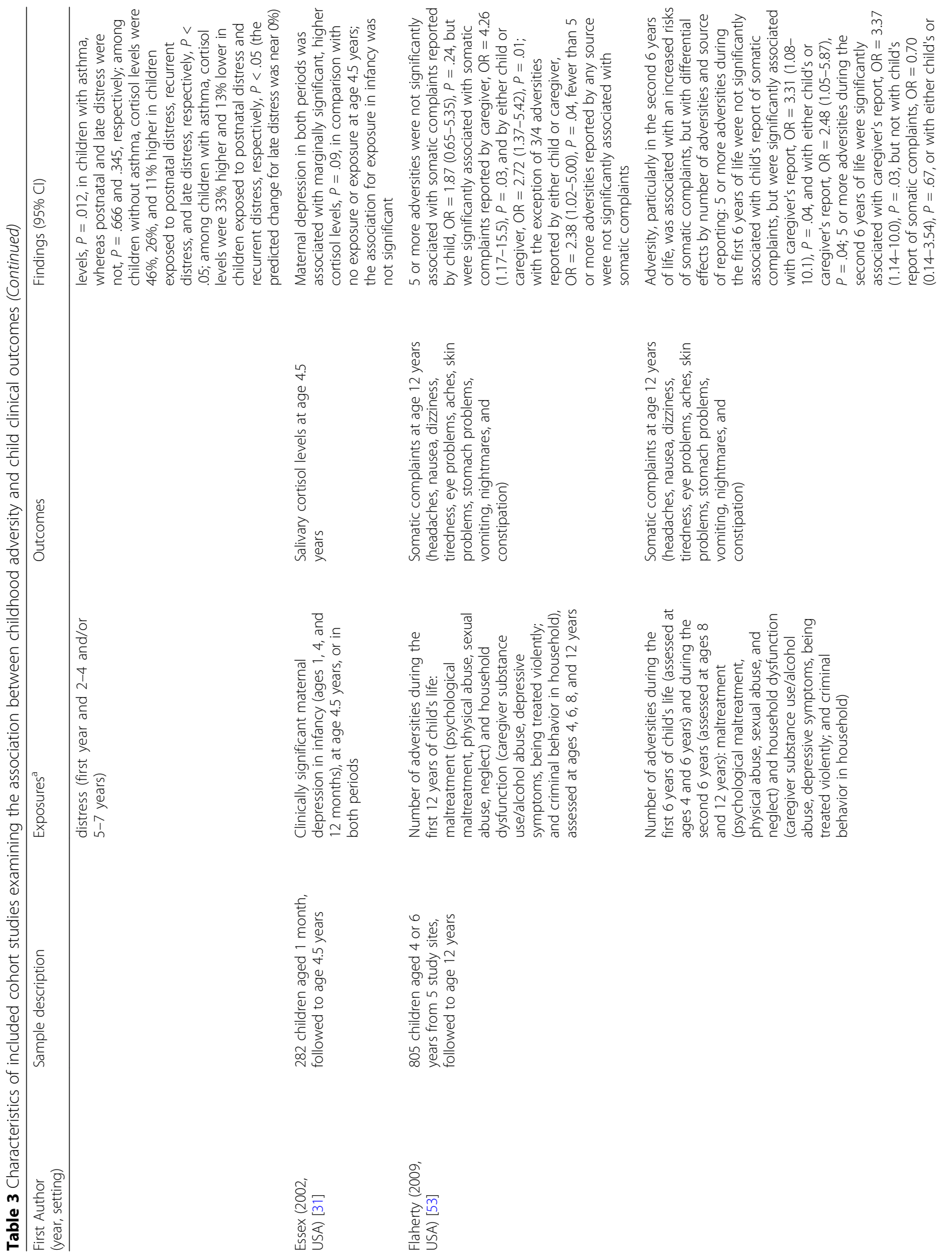




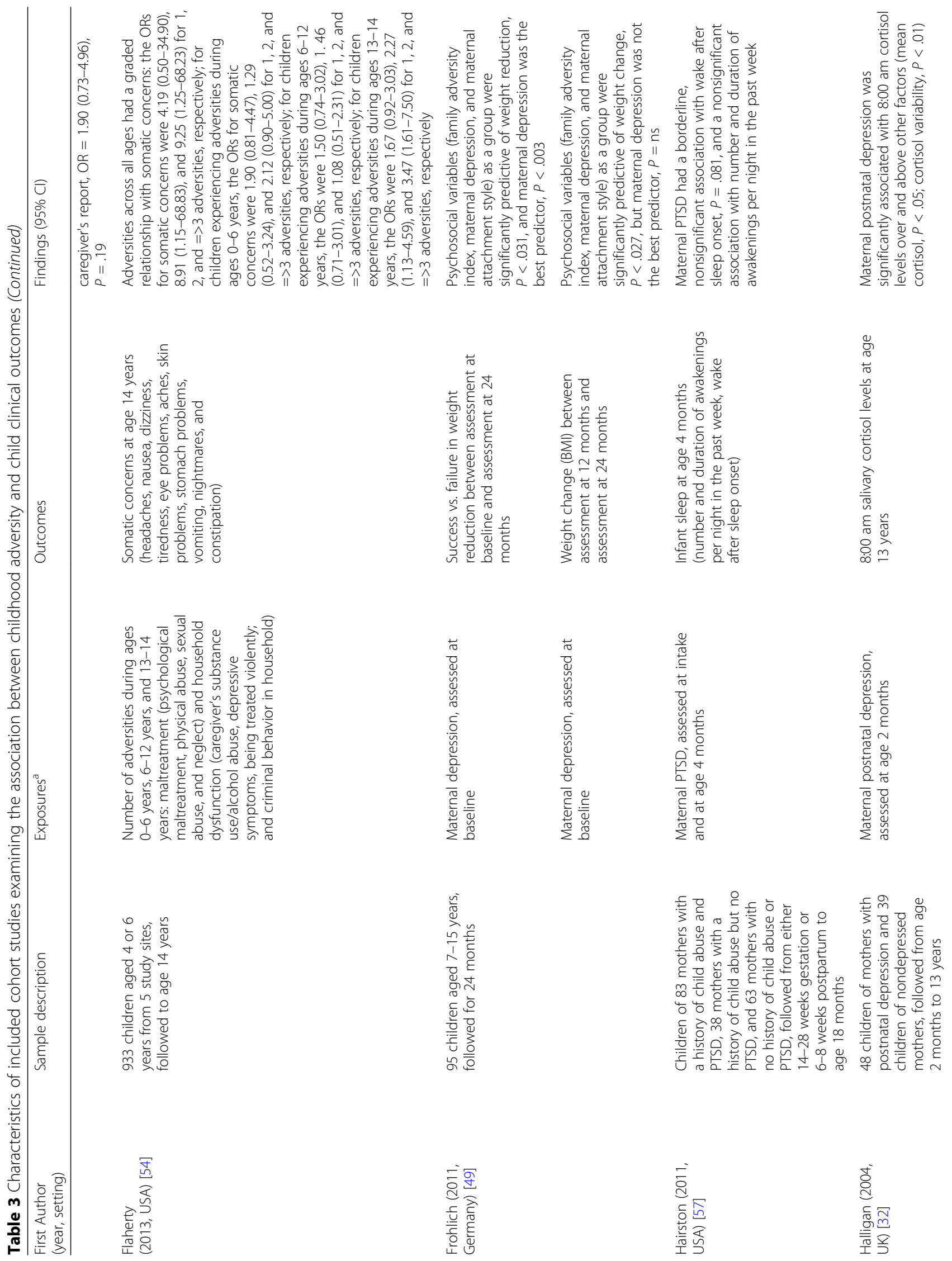




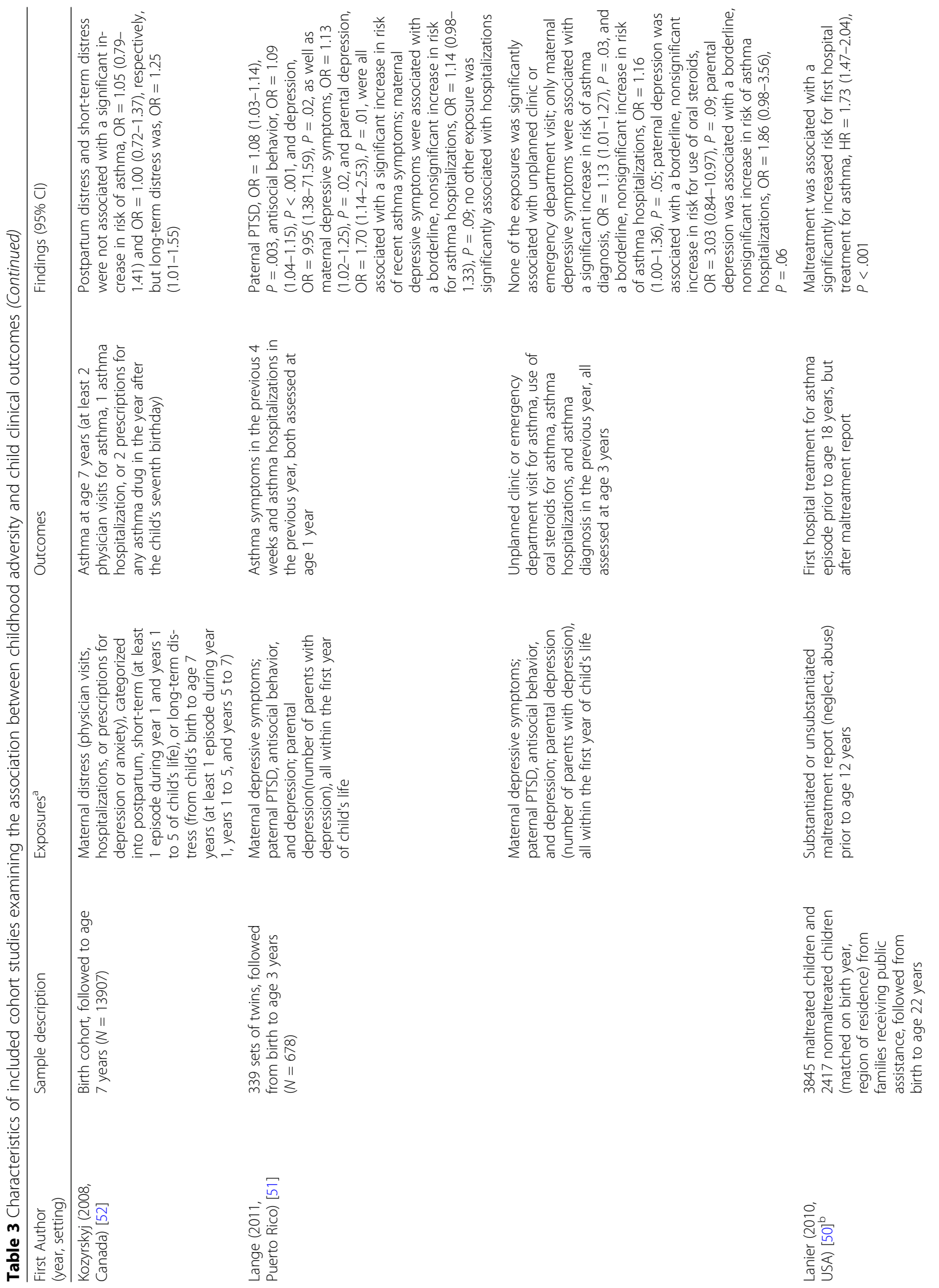




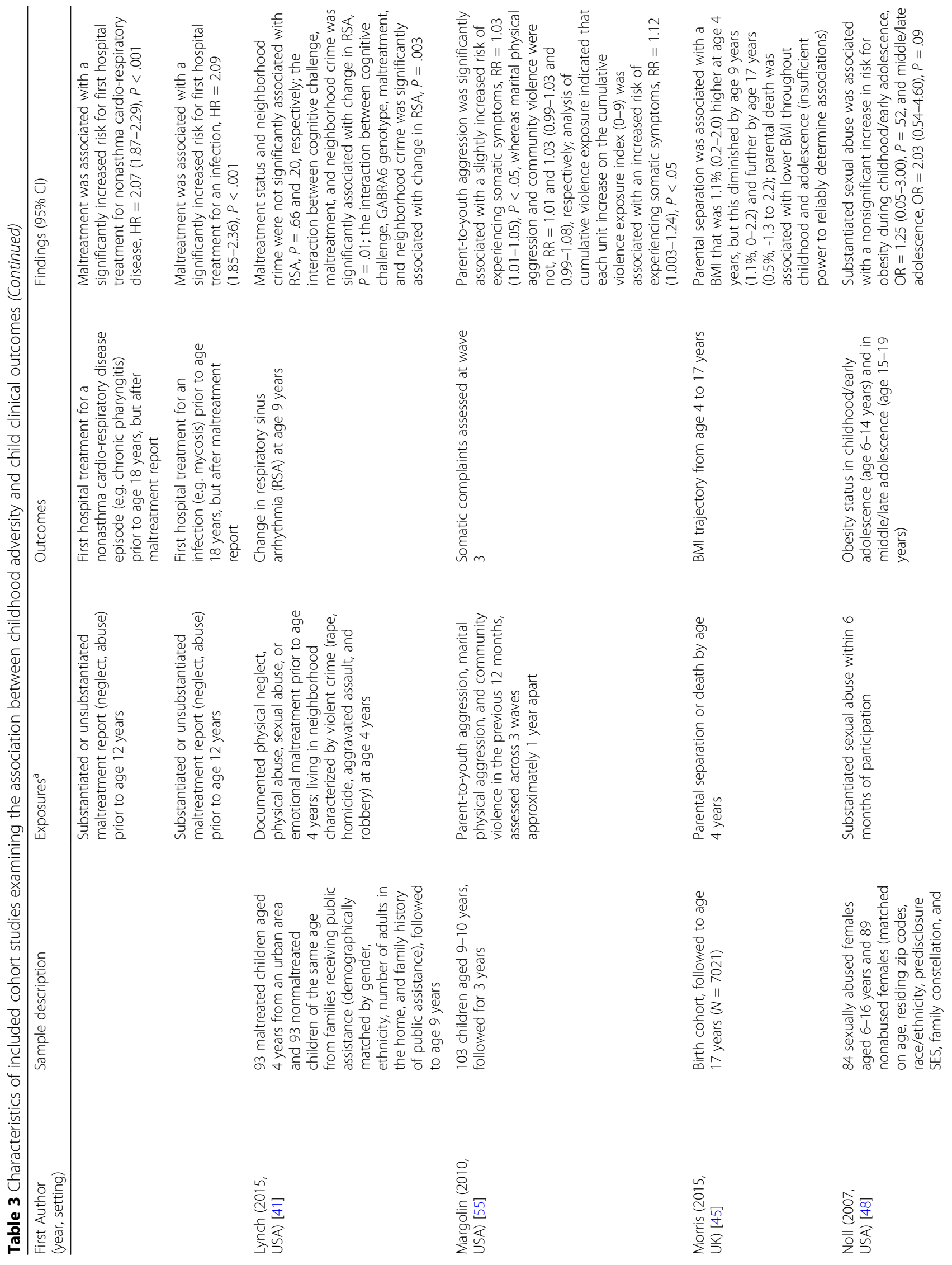




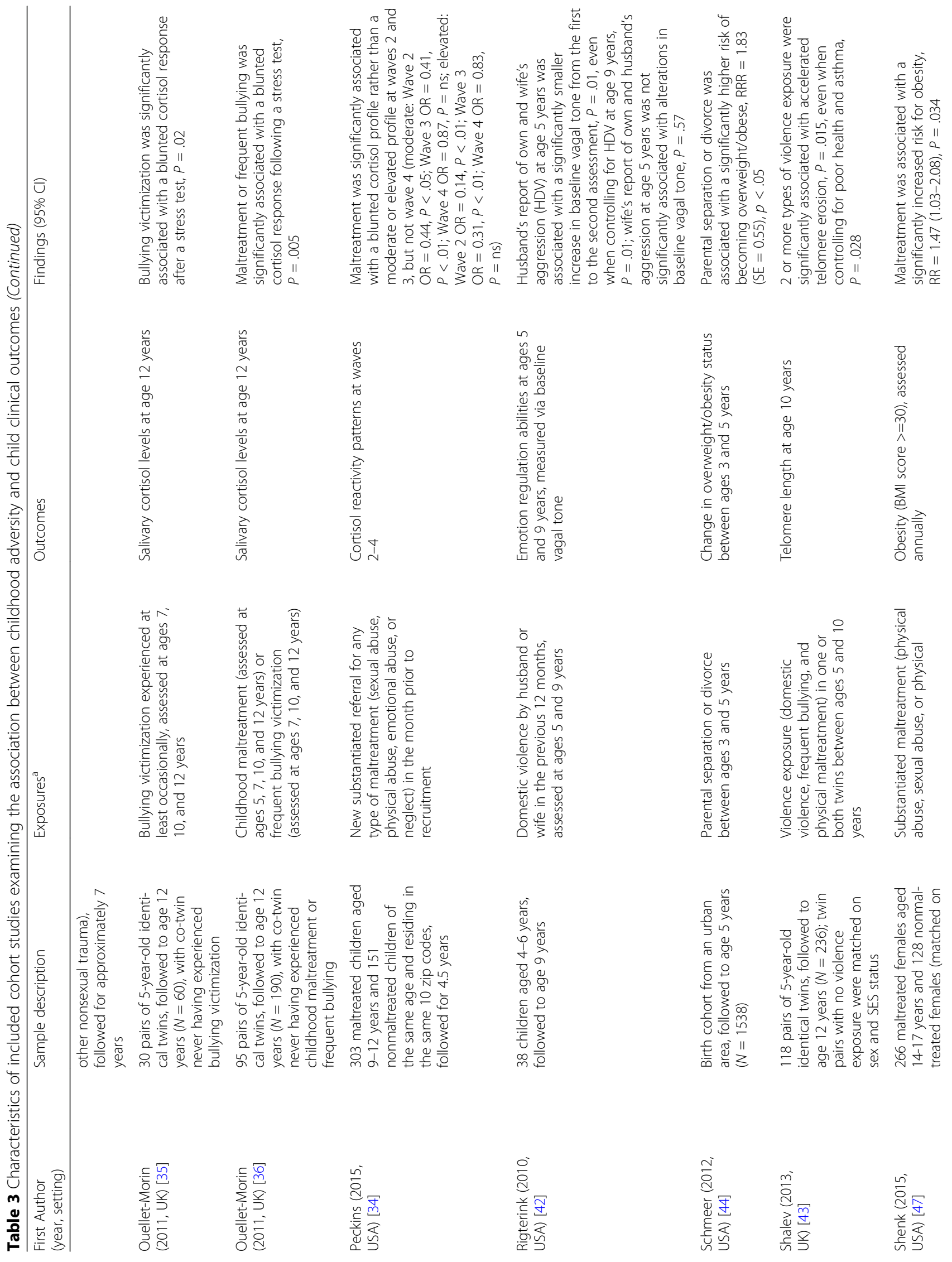




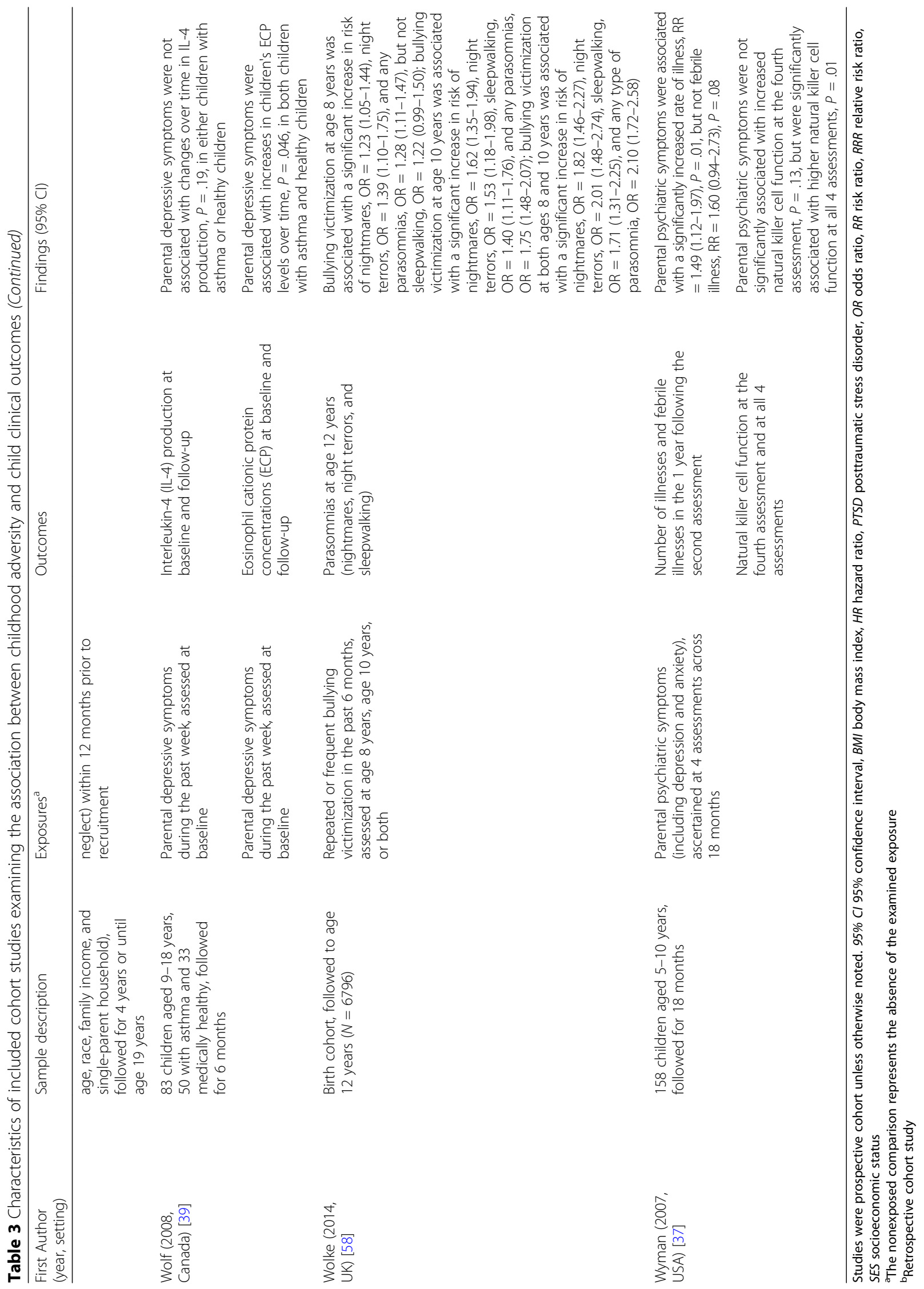




\section{Clinical outcomes}

Of the 29 selected studies investigating clinical outcomes, 14 focused on biological markers. Of these studies, 7 examined markers of endocrine function (cortisol), 4 examined markers of inflammation and immune function, 2 examined markers of autonomic nervous function, and 1 examined telomere length. Other clinical outcomes reported included obesity (6 studies), asthma (3 studies), infections and illnesses (3 studies), somatic complaints (3 studies), and sleep (3 studies).

\section{Biological markers of endocrine function}

Studies on cortisol, a stress hormone with a diurnal pattern of secretion, give insight to the dysregulation of the stress response in children exposed to adversity. Of the 7 selected studies that examined cortisol, 4 investigated the effect of maternal mental health on cortisol secretion and showed that results varied with age of exposure. Dreger et al found that maternal postnatal and recurrent distress were significantly associated with higher midday serum cortisol levels in 7-10-year-olds [30]. Essex et al assessed children's afternoon or evening salivary cortisol levels and found that those who were exposed to maternal depression both in infancy and at age 4.5 years had marginally significant, higher cortisol levels at age 4.5 years than did children never exposed or exposed only at age 4.5 years. In addition, children exposed to maternal depression only in infancy did not have significantly higher cortisol levels [31]. Halligan et al found that maternal postnatal depression was associated with higher, more variable morning salivary cortisol in 13-year-old children [32]. Ashman et al compared 78-year-old children of depressed and nondepressed mothers and found no effect of maternal depression on salivary cortisol levels or diurnal rhythm of cortisol [33].

In contrast, the 3 studies examining the effect of maltreatment on children's cortisol production reported lower cortisol levels in maltreated children. Peckins et al found that maltreated children were more likely than nonmaltreated children to have a blunted cortisol profile rather than a moderate or an elevated profile, but by late adolescence there was no longer a difference [34]. Two studies on cortisol response to a psychosocial stress test in 12-year-old twins indicated that maltreated or frequently bullied children did not exhibit the expected increase in cortisol following the stress test $[35,36]$.

\section{Biological markers of inflammation and immune function}

The reviewed studies indicated alterations of immune and inflammatory response in children exposed to adversity. In a sample of children exposed to their parents' psychiatric symptoms, Wyman et al [37] and Caserta et al [38] found that higher levels of symptoms were associated with enhanced natural killer cell response in children, suggesting that chronic stress may exert effects of cytotoxicity on the developing immune system. Wolf et al found that greater parental depressive symptoms at baseline predicted increases in children's profiles of asthma-relevant inflammatory markers (i.e. eosinophil cationic protein and interleukin-4), in both children with asthma and controls [39]. In 3 cohorts of children, Copeland et al did not find an association between bullying or teasing and C-reactive protein levels (a marker of inflammation in the body) [40].

\section{Biological markers of autonomic nervous function}

Lynch et al found that the interaction between exposure to neighborhood crime, exposure to maltreatment, and children's genotype was associated with different patterns of respiratory sinus arrhythmia reactivity, a measure of the vagal tone indicating the physiological response of the autonomic nervous system to stress [41]. Rigterink et al found that exposure to domestic violence was associated with differences in the physiological regulation of emotion-measured as vagal tone-between exposed and nonexposed children, with smaller increases in baseline vagal tone in exposed children, suggesting a less adaptive development of regulatory functioning over time among these children [42].

\section{Telomere length}

One study investigated the relationship between violence exposure and telomere length, a marker of cellular age that also correlates with disease morbidity and mortality. Shalev et al observed stress-related accelerated telomere erosion in children who experienced 2 or more types of violence exposure, providing support for a mechanism linking cumulative childhood stress to potential lifelong and transgenerational health impacts [43].

\section{Obesity}

Evidence for early adversity influencing weight or body mass index (BMI) in childhood was mixed, with different types of adversity resulting in varying outcomes at different ages. Schmeer found that children whose mothers dissolved a union had an $80 \%$ higher risk of becoming overweight or obese between ages 3 and 5 years, as compared with children of stable married mothers [44]. Morris et al found that children whose parents had separated had a BMI 1.1\% (95\% CI: 0.2-2.0) higher at age 4 years in comparison with children whose parents remained together, but this diminished to $0.5 \%$ (95\% CI: $-1.3-2.2$ ) by age 17 years [45]. Boynton-Jarrett et al found that children whose mothers reported chronic intimate partner violence (IPV) were more likely to be obese at age 5 years than were children whose mothers reported no IPV $(\mathrm{OR}=1.80,95 \%$ CI: 1.24-2.61), whereas children who were exposed to either early (up 


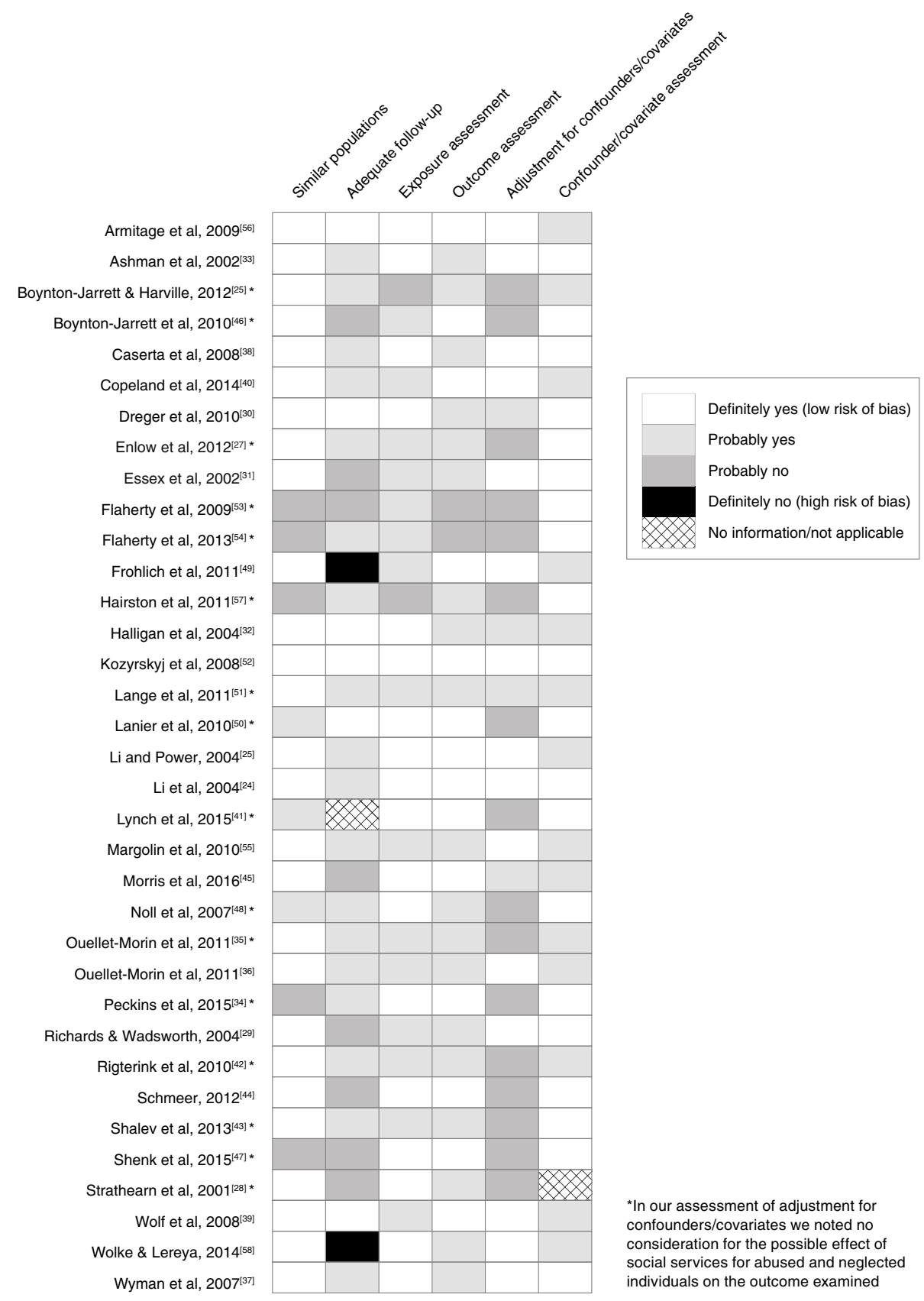

Fig. 2 Risk of bias in selected studies

to age 12 months) or late (at age 3 and/or 5 years) maternal IPV did not have a significant increase in risk. Analyses stratified by sex indicated an increased risk for obesity only among females exposed to maternal chronic IPV (OR = 2.21, 95\% CI: 1.30-3.75), as compared with males $(\mathrm{OR}=1.66,95 \% \mathrm{CI}: 0.94-2.93)$ [46].

Studies on household dysfunction showed an effect on weight during early childhood, whereas studies on abuse and neglect reported an effect on weight during adolescence. Shenk et al found that maltreatment significantly increased the risk for obesity among female adolescents (RR $=1.47,95 \%$ CI: 1.03-2.08, $P=.034)$ [47]. Noll et al found a borderline, nonsignificant increase in risk for obesity during middle/late adolescence (age 15-19 years) for females who had been sexually abused $(\mathrm{OR}=2.03$, 95\% CI: $0.54-4.60, P=.09$ ); the relationship was not significant during childhood/early adolescence (age 6-14 years) [48].

Childhood adversity also showed an effect on children's ability to manage their weight. Frohlich et al 
examined weight change among overweight and obese 7-15-year-olds participating in a weight reduction intervention. They found that psychosocial variables-family adversity, maternal depression, and maternal attachment style-were significantly predictive of long-term success in weight reduction [49].

\section{Asthma}

Studies reported that children exposed to childhood adversity had an increased risk for asthma. Lanier et al found that maltreatment significantly increased the risk for first hospital treatment for asthma (HR $=1.73$, 95\% CI: $1.47-2.04, P<.001)$ [50]. Lange et al found that paternal posttraumatic stress disorder (PTSD; OR $=1.08$, 95\% CI: 1.03-1.14, $P=.003$ ), paternal major depressive episode $(\mathrm{OR}=9.95,95 \% \mathrm{CI}: 1.38-71.59, P=.02)$, and paternal antisocial behavior $(\mathrm{OR}=1.09,95 \% \mathrm{CI}$ : $1.04-$ $1.15, P<.001)$, as well as maternal depressive symptoms $(\mathrm{OR}=1.13,95 \% \mathrm{CI}: 1.02-1.25, P=.02)$ and parental depression $(\mathrm{OR}=1.70,95 \% \mathrm{CI}: 1.14-2.53, P=.01)$ were associated with recent asthma symptoms at age 1 year. At age 3 years, maternal depressive symptoms showed a significant association with asthma diagnosis $(\mathrm{OR}=1.13$, 95\% CI: 1.01-1.27, $P=.03$ ) and a borderline, significant association with hospitalizations for asthma $(\mathrm{OR}=1.16$, 95\% CI: 1.00-1.36, $P=.05$ ). Paternal major depressive episode and parental depression had a borderline, nonsignificant association with oral steroid treatment $(\mathrm{OR}=$ 3.03, 95\% CI: $0.84-10.97, P=.09$ ) and hospitalizations for asthma (OR $=1.86,95 \%$ CI: $0.98-3.56, P=.06)$ [51]. In addition, Kozyrskyj et al found that maternal longterm distress was significantly associated with an increased risk of asthma at age 7 years (OR $=1.25,95 \%$ CI: 1.01-1.55), but postpartum distress and short-term distress were not [52].

\section{Infections and illnesses}

An increased risk for infection was also reported to be associated with childhood adversity. Lanier et al found that maltreatment increased the risk for first hospital treatment for non-asthma-related cardiorespiratory disease (e.g. acute respiratory infection; $H R=2.07,95 \%$ CI: $1.87-2.29, \mathrm{P}<.001$ ) as well as other infections (e.g. mycoses; HR $=2.09,95 \%$ CI: $1.85-2.36, P<.001)$ [50]. Wyman et al studied a sample of children 5-10 years of age and found that after 18 months of follow-up, children of parents reporting higher levels of psychiatric symptoms had more illnesses $(\mathrm{RR}=1.49$, 95\% CI: 1.12 1.97, $P=.01)$, but not more febrile illnesses $(\mathrm{RR}=1.60$, 95\% CI: 0.94-2.73, $P=.08$ ) [37]. At the 3-year followup, Caserta et al found that children of parents reporting higher levels of psychiatric symptoms continued to experience more illnesses $(\mathrm{RR}=1.40,95 \% \mathrm{CI}: 1.06-1.85$,
$P=.02)$, but they also experienced more febrile illnesses $(\mathrm{RR}=1.77,95 \%$ CI: 1.00-3.13, $P=.05)$ [38].

\section{Somatic complaints}

The relationship between childhood adversity and somatic complaints (i.e. common physical complaints of uncertain origin such as headaches and nausea) varied by number and types of adversities. Flaherty et al found that experiencing 5 or more adversities during childhood was not associated with child somatic complaints reported by the child at age 12 years, but was associated with child somatic complaints reported by the caregiver $(\mathrm{OR}=4.26,95 \% \mathrm{CI}: 1.17-15.5, P=.03)$ [53]. In a subsequent study, Flaherty et al examined somatic concerns reported at age 14 years and found a graded relationship between exposure to adversity across all ages and child somatic concerns reported by the caregiver; ORs $(95 \%$ CI) for somatic concerns were 4.19 (0.50$34.90), 8.91$ (1.15-68.83), and $9.25(1.25-68.23)$ for 1 , 2 , and $\geq 3$ adversities, respectively [54]. Margolin et al found that parent-to-youth aggression was significantly associated with a slightly increased risk of experiencing somatic symptoms $(\mathrm{RR}=1.03,95 \% \mathrm{CI}$ : $1.01-1.05, P<.05)$, whereas marital physical aggression and community violence were not $(\mathrm{RR}=1.01$, 95\% CI: $0.99-1.03$ and $\mathrm{RR}=1.03,95 \%$ CI: $0.99-1.08$, respectively) [55].

\section{Sleep}

Childhood adversity was also shown to affect children's sleep. In a study on the effect of maternal depression on infant sleep, Armitage et al found that average sleep time in 24 hours did not differ between children of depressed and nondepressed mothers at 2 or 24 weeks, but nocturnal sleep was 97 min longer among children of nondepressed mothers at both 2 and 24 weeks, and these children had fewer awakenings during the night than did children of depressed mothers [56]. In examining the effect of maternal PTSD on infant sleep, Hairston et al. found a marginally significant association for infant waking after sleep onset and a nonsignificant association for amount of time awake during the night [57]. Wolke and Lereya found that bullying victimization at both ages 8 and 10 years was associated with nightmares $(\mathrm{OR}=1.82,95 \% \mathrm{CI}: 1.46-2.27)$, night terrors $(\mathrm{OR}=$ 2.01, 95\% CI: 1.48-2.74), sleepwalking $(\mathrm{OR}=1.71$, 95\% CI: $1.31-2.25$ ), and any type of parasomnia (OR $=2.10,95 \%$ CI: $1.72-2.58)$ at age 12 years [58].

\section{Discussion}

To date, the majority of scientific inquiry on childhood adversity and biological health outcomes has focused on adult outcomes. Furthermore, most pediatric studies 
have been cross-sectional in nature, making it difficult to determine the temporal relationship between exposures to adversity and biological health outcomes. This systematic review synthesized the longitudinal evidence on childhood adversity and pediatric health outcomes to help provide insight into the link between early manifestations of a dysregulated stress response and biological health outcomes. Outcomes identified represent a range of conditions, which reflects the multiple systems impacted by a chronically dysregulated stress response in childhood. We observed great variability in the results of the longitudinal studies included in this review, suggesting that it is critical to consider both the nature of the adversity and the individual characteristics of the exposed child.

The evidence from the selected longitudinal studies on cognitive delays, asthma, infections, somatic complaints, and sleep disruptions revealed associations between childhood adversity and increased risk of these conditions; this evidence adds to that from other nonlongitudinal studies in children [59-68]. This review also revealed mixed results related to obesity and physical development, with variability by age, sex, and exposure type. The variable findings may be due to bias related to loss to follow-up; however, genetic and environmental factors also may have influenced the heterogeneous response to childhood adversity [69-74]. Though a minority of the studies in this review focused on biomarkers, the growth of research and technology in this domain will help elucidate the biological mechanisms underlying the relationship between childhood adversity and health outcomes. Studies on cortisol included in this review used different sources (e.g. saliva, blood) and times of measurement, making it difficult to compare results across studies. In addition, the diverse effects of adversity observed on cortisol secretion may have been due to participant group differences and loss to follow-up. Nonetheless, the selected studies pointed to both elevated and blunted cortisol profiles, which might be indicative of a spectrum of responses that ranges from an initial increased activation of the stress response to a depletion of cortisol secretion over time, both of which can be detrimental to a child's developing body $[75,76]$. The reviewed studies also reported altered profiles of markers of inflammatory, immune, and autonomic nervous system functions, and epigenetic factors, highlighting the complexity of the biological response to adversity. It should be noted that, in general, the effect sizes reported across the various studies were small, which could be an accurate reflection of the small differences adversity exerts on the childhood outcomes we captured in this review or it could be an indication of methodological issues such as measurement or confounding.

\section{Strengths and limitations}

This systematic review's strengths include a wide publication window and a variety of search terms to capture studies on adversity. Limitations include exclusion of non-full-text and nonjournal publications, publication bias, and use of only 3 databases. We also did not contact authors for additional data or clarification. Another limitation is that definitions used for childhood adversity in the literature vary, making it challenging to perform a search to identify all sources of adversity. Furthermore, although most of the studies in this review examined more than one childhood adversity and some examined cumulative adversity, we did not explicitly focus on polyvictimization in our search, selection processes, or synthesis. Moreover, because the goal of this review was to broadly investigate relationships between a wide variety of adversities and health outcomes, we did not examine timing or severity of each individual type of adversity. Polyvictimization, timing, and severity are important aspects of childhood adversity [18, 77], and future studies in these areas may give insight to the complex mechanisms underlying the dysregulation of the stress response.

\section{Conclusions}

This systematic review adds to the growing evidence on the relationship between childhood adversity and children's health. In particular, this review provides support for two important concepts:

1. Childhood adversity affects brain development and multiple body systems, and the physiologic manifestations are detectable in childhood. Although pediatricians can often recognize the behavioral signs associated with exposure to adversity [78], the evidence from this review suggests that pediatricians should also consider such exposure when evaluating the differential diagnosis of pediatric conditions such as developmental delay, asthma, somatic complaints, recurrent infections requiring hospitalization, and sleep disruption, which were found to be consistently associated with adversity in the selected studies. Although clinical diagnostic guidelines for detecting a toxic stress response in children do not yet exist, these conditions might provide part of the basis for the development of such guidelines.

2. The variability in children's response to adversity suggests complex underlying mechanisms, including the timing and severity of adversity, the experience of cumulative adversity, and the presence of protective factors (i.e. resilience, genetic and epigenetic constitution, individual socioeconomic status) that mitigate or exacerbate the impact of the exposure. 
This variability poses a challenge for the development of uniform diagnostic guidelines $[79,80]$.

Screening for exposure to childhood adversity, protective factors, and impacts of a toxic stress response could be the first step in providing targeted support for children at risk and their caregivers. In addition to screening, the American Academy of Pediatrics and other child health experts have also recommended strategies such as integrating behavioral healthcare into the pediatric home, offering parental support, providing peer-based education, and identifying community resources to help enhance resilience and mitigate the downstream effects of childhood adversity [81-88].

This systematic review provides a foundation for future research on the longitudinal relationship between childhood adversity and biological health outcomes. Future studies should examine in detail the findings we observed, taking into consideration timing and severity of adversity, the experience of cumulative adversity, and the presence of protective factors. This may be especially critical for outcomes for which we found mixed results, such as with physical development, obesity, and cortisol secretion. In addition, more large longitudinal studies are needed to develop a greater understanding of the causal pathways from exposure to childhood adversity to disease risk, to help the pediatric community develop services and interventions, identify protective factors, and prevent long-term negative health outcomes.

\section{Abbreviations}

ACE: Adverse childhood experience; Cl: Confidence interval; HR: Hazard ratio; IPV: Intimate partner violence; OR: Odds ratio; RR: Risk ratio

\section{Acknowledgements}

We would like to acknowledge the JPB Foundation for their generous support, the staff of Center for Youth Wellness for their commitment, Allison Ipsen for her assistance with this project, and Susan Briner for her invaluable insight.

\section{Funding}

All phases of this study were supported by the JPB Foundation and the Center for Youth Wellness.

\section{Availability of data and materials}

The datasets used and/or analysed during the current study are available from the corresponding author on reasonable request.

\section{Authors' contributions}

DLO conceptualized and designed the study; performed the study selection, data extraction, and data analysis; and drafted the initial manuscript. PJ performed the study selection, data extraction, and data analysis; and helped draft, review, and revise the manuscript. SSM helped to conceptualize and design the study, performed the data extraction, and reviewed and revised the manuscript. KK and SP helped to design the study, performed the data extraction, and reviewed and revised the manuscript. NBH helped to conceptualize the study, and reviewed and revised the manuscript. MB helped to conceptualize and design the study; and helped draft, review, and revise the manuscript. All authors approved the final manuscript as submitted and agree to be accountable for all aspects of the work.
Ethics approval and consent to participate

Not applicable.

\section{Consent for publication}

Not applicable.

\section{Competing interests}

The authors declare that they have no competing interests.

\section{Publisher's Note}

Springer Nature remains neutral with regard to jurisdictional claims in published maps and institutional affiliations.

\section{Author details}

${ }^{1}$ Center for Youth Wellness, 3450 Third Street, Bldg 2, Ste 201, San Francisco, CA 94124, USA. ${ }^{2}$ Human Impact Partners, Oakland, California, USA.

Received: 24 May 2017 Accepted: 30 January 2018

Published online: 23 February 2018

\section{References}

1. Shonkoff JP. Leveraging the biology of adversity to address the roots of disparities in health and development. Proc Natl Acad Sci USA. 2012; https://doi.org/10.1073/pnas.1121259109.

2. Fox SE, Levitt P, Nelson CA. How the timing and quality of early experiences influence the development of brain architecture. Child Dev. 2010; https://doi.org/10.1111/j.1467-8624.2009.01380.x.

3. Meaney MJ. Epigenetics and the biological definition of gene $x$ environment interactions. Child Dev. 2010; https://doi.org/10.1111/j.14678624.2009.01381.x.

4. Shonkoff JP, Boyce WT, McEwen BS. Neuroscience, molecular biology, and the childhood roots of health disparities: building a new framework for health promotion and disease prevention. JAMA. 2009; https://doi.org/10, 1001/jama.2009.754.

5. National Scientific Council on the Developing Child. Excessive Stress Disrupts the Architecture of the Developing Brain: Working Paper 3. Updated edition, 2014. http://developingchild.harvard.edu/resources/wp3. Accessed 19 Dec, 2015.

6. McEwen BS. Stress, adaptation, and disease. Allostasis and allostatic load. Ann NY Acad Sci. 1998;840:33-44

7. Lupien SJ. Effects of stress throughout the lifespan on the brain, behaviour and cognition. Nat Rev Neurosci. 2009; https://doi.org/10.1038/nrn2639.

8. Bucci M, Marques SS, Oh D, Harris NB. Toxic stress in children and adolescents. Advances in Pediatrics. 2016; https://doi.org/10.1016/j.yapd.2016. 04.002 .

9. Felitti VJ, Anda RF, Nordenberg D, et al. Relationship of childhood abuse and household dysfunction to many of the leading causes of death in adults. The Adverse Childhood Experiences (ACE) Study. Am J Prev Med. 1998; 14(4):245-58

10. Gilbert LK, Breiding MJ, Merrick MT, et al. Childhood adversity and adult chronic disease: an update from ten states and the District of Columbia, 2010. Am J Prev Med. 2015; https://doi.org/10.1016/j.amepre. 2014.09.006.

11. Campbell JA, Walker RJ, Egede LE. Associations between adverse childhood experiences, high-risk behaviors, and morbidity in adulthood. Am J Prev Med. 2016; https://doi.org/10.1016/j.amepre.2015.07.022.

12. Kalmakis KA, Chandler GE. Health consequences of adverse childhood experiences: a systematic review. J Am Assoc Nurse Pract. 2015; https://doi.org/10.1002/2327-6924.12215.

13. Williamson DF, Thompson TJ, Anda RF, Dietz WH, Body FV. weight and obesity in adults and self-reported abuse in childhood. Int J Obes Relat Metab Disord. 2002; https://doi.org/10.1038/sj.jjo.0802038.

14. Brown DW, Anda RF, Tiemeier $\mathrm{H}$, et al. Adverse childhood experiences and the risk of premature mortality. Am J Prev Med. 2009; https://doi.org/10. 1016/j.amepre.2009.06.021.

15. Brown DW, Anda RF, Felitti VJ, et al. Adverse childhood experiences are associated with the risk of lung cancer: a prospective cohort study. BMC Public Health. 2010; https://doi.org/10.1186/1471-2458-10-20.

16. Hardt J, Rutter M. Validity of adult retrospective reports of adverse childhood experiences: review of the evidence. J Child Psychol Psychiatry. 2004;45(2):260-73. 
17. Reuben A, Moffitt TE, Caspi A, et al. Lest we forget: comparing retrospective and prospective assessments of adverse childhood experiences in the prediction of adult health. J Child Psychol Psychiatry. 2016; https://doi.org/10.1111/jcpp.12621.

18. Bright MA, Knapp C, Hinojosa MS, Alford S, Bonner B. The comorbidity of physical, mental, and developmental conditions associated with childhood adversity: a population based study. Matern Child Health J. 2016; https://doi.org/10.1007/s10995-015-1915-7.

19. Stein RE, Hurlburt MS, Heneghan AM, et al. Chronic conditions among children investigated by child welfare: a national sample. Pediatrics. 2013; https://doi.org/10.1542/peds. 2012-1774.

20. Sills MR, Shetterly S. Xu S, Magid D, Kempe A. Association between parental depression and children's health care use. Pediatrics. 2007; https://doi.org/ 10.1542/peds.2006-2399.

21. Moher D, Liberati A, Tetzlaff J, Altman DG. The PRISMA Group. Preferred reporting items for systematic reviews and meta-analyses: the PRISMA statement. PLoS Med. 2009; https://doi.org/10.1371/journal.pmed1000097.

22. Burke Harris N, Renschler T. Center for Youth Wellness ACE-Questionnaire (CYW ACE-Q Child, Teen, Teen SR). Version 7. San Francisco, CA: Center for Youth Wellness; 2015.

23. Tool to Assess Risk of Bias in Cohort Studies. 2014. https://www. evidencepartners.com/wp-content/uploads/2014/02/Tool-to-Assess-Risk-ofBias-in-Cohort-Studies.doc. Accessed 22 May 2017.

24. Li L, Manor O, Power C. Early environment and child-to-adult growth trajectories in the 1958 British birth cohort. Am J Clin Nutr. 2004;80(1):185-92.

25. Li L, Power C. Influences on childhood height: comparing two generations in the 1958 British birth cohort. Int J Epidemiol. 2004; https://doi.org/10. 1093/ije/dyh325.

26. Boynton-Jarrett R, Harville EW. A prospective study of childhood social hardships and age at menarche. Ann Epidemiol. 2012; https://doi.org/10. 1016/j.annepidem.2012.08.005.

27. Enlow MB, Egeland B, Blood EA, Wright RO, Wright RJ. Interpersonal trauma exposure and cognitive development in children to age 8 years: a longitudinal study. J Epidemiol Community Health. 2012; https://doi.org/10. 1136/jech-2011-200727.

28. Strathearn L, Gray PH, O'Callaghan MJ, Wood DO. Childhood neglect and cognitive development in extremely low birth weight infants: a prospective study. Pediatrics. 2001;108(1):142-51.

29. Richards M, Wadsworth ME. Long term effects of early adversity on cognitive function. Arch Dis Child. 2004; https://doi.org/10.1136/adc.2003. 032490.

30. Dreger LC, Kozyrskyj AL, HayGlass KT, Becker AB, MacNeil BJ. Lower cortisol levels in children with asthma exposed to recurrent maternal distress from birth. J Allergy Clin Immunol. 2010; https://doi.org/10.1016/j.jaci.2009.09.051.

31. Essex MJ, Klein MH, Cho E, Kalin NH. Maternal stress beginning in infancy may sensitize children to later stress exposure: effects on cortisol and behavior. Biol Psychiatry. 2002; http://dx.doi.org/10.1016/S00063223(02)01553-6.

32. Halligan SL, Herbert J, Goodyer IM, Murray L. Exposure to postnatal depression predicts elevated cortisol in adolescent offspring. Biol Psychiatry. 2004; http://dx.doi.org/10.1016/j.biopsych.2003.09.013.

33. Ashman SB, Dawson G, Panagiotides H, Yamada E, Wilkinson CW. Stress hormone levels of children of depressed mothers. Dev Psychopathol. 2002; https://doi.org/10.1017/S0954579402002080.

34. Peckins MK, Susman EJ, Negriff S, Noll J, Cortisol TPK. profiles: A test for adaptive calibration of the stress response system in maltreated and nonmaltreated youth. Dev Psychopathol. 2015; https://doi.org/10.1017/ S0954579415000875.

35. Ouellet-Morin I, Danese A, Bowes L, et al. A discordant monozygotic twin design shows blunted cortisol reactivity among bullied children. J Am Acad Child Adolesc Psychiatry. 2011; https://doi.org/10.1016/j.jaac.2011.02.015.

36. Ouellet-Morin I, Odgers CL, Danese A, et al. Blunted cortisol responses to stress signal social and behavioral problems among maltreated/bullied 12year-old children. Biol Psychiatry. 2011; https://doi.org/10.1016/j.biopsych. 2011.06.017

37. Wyman PA, Moynihan J, Eberly S, et al. Association of family stress with natural killer cell activity and the frequency of illnesses in children. Arch Pediatr Adolesc Med. 2007; https://doi.org/10.1001/archpedi.161.3.228.

38. Caserta MT, O'Connor TG, Wyman PA, et al. The Associations between psychosocial stress and the frequency of illness, and innate and adaptive immune function in children. Brain Behav Immun. 2008; https://doi.org/10. 1016/j.bbi.2008.01.007.

39. Wolf JM, Miller GE, Chen E. Parent psychological states predict changes in inflammatory markers in children with asthma and healthy children. Brain Behav Immun. 2008; https://doi.org/10.1016/j.bbi.2007.10.016.

40. Copeland WE, Wolke D, Lereya ST, et al. Childhood bullying involvement predicts low-grade systemic inflammation into adulthood. PNAS. 2014; https://doi.org/10.1073/pnas.1323641111.

41. Lynch M, Manly JT, Cicchetti D. A multilevel prediction of physiological response to challenge: interactions among child maltreatment, neighborhood crime, endothelial nitric oxide synthase gene (eNOS), and GABA(A) receptor subunit alpha-6 gene (GABRA6). Dev Psychopathol. 2015; https://doi.org/10.1017/S0954579415000887.

42. Rigterink T, Fainsilber KL, Hessler DM. Domestic violence and longitudinal associations with children's physiological regulation abilities. J Interpers Violence. 2010; https://doi.org/10.1177/0886260509354589.

43. Shalev I, Moffitt TE, Sugden K. Exposure to violence during childhood is associated with telomere erosion from 5 to 10 years of age: a longitudinal study. Mol Psychiatry. 2013; https://doi.org/10.1038/mp.2012.32.

44. Schmeer KK. Family structure and obesity in early childhood. Soc Sci Res. 2012; http://dx.doi.org/10.1016/j.ssresearch.2012.01.007.

45. Morris TT, Northstone K, Howe LD. Examining the association between early life social adversity and BMI changes in childhood: a life course trajectory analysis. Pediatr Obes. 2016; https://doi.org/10.1111/ijpo.12063.

46. Boynton-Jarrett R, Fargnoli J, Suglia SF, Zuckerman B, Wright RJ. Association between maternal intimate partner violence and incident obesity in preschool-aged children: results from the Fragile Families and Child Wellbeing Study. Arch Pediatr Adolesc Med. 2010; https://doi.org/10.1001/ archpediatrics.2010.94.

47. Shenk CE, Noll JG, Peugh JL, Griffin AM, Bensman HE. Contamination in the Prospective Study of Child Maltreatment and Female Adolescent Health. J Pediatr Psychol. 2016; https://doi.org/10.1093/jpepsy/jsv017.

48. Noll JG, Zeller MH, Trickett PK, Obesity PFW. risk for female victims of childhood sexual abuse: a prospective study. Pediatrics. 2007; https://doi. org/10.1542/peds.2006-3058.

49. Frohlich G, Pott W, Albayrak Ö, Hebebrand J, Conditions P-PU. of long-term success in a lifestyle intervention for overweight and obese youths. Pediatrics. 2011; https://doi.org/10.1542/peds.2010-3395.

50. Lanier P, Jonson-Reid M, Stahlschmidt MJ, Drake B, Constantino J. Child maltreatment and pediatric health outcomes: a longitudinal study of lowincome children. J Pediatr Psychol. 2010; https://doi.org/10.1093/jpepsy/jsp086.

51. Lange NE, Bunyavanich S, Silberg JL, Canino G, Rosner BA, Celedón JC. Parental psychosocial stress and asthma morbidity in Puerto Rican twins. J Allergy Clin Immunol. 2011; https://doi.org/10.1016/j.jaci.2010.11.010.

52. Kozyrskyj AL, Mai XM, McGrath P, Hayglass KT, Becker AB, Macneil B. Continued exposure to maternal distress in early life is associated with an increased risk of childhood asthma. Am J Respir Crit Care Med. 2008; http://dx.doi.org/10.1164/rccm.200703-3810C.

53. Flaherty EG, Thompson R, Litrownik AJ, et al. Adverse childhood exposures and reported child health at age 12. Acad Pediatr. 2009; http://dx.doi.org/10. 1016/j.acap.2008.11.003.

54. Flaherty EG, Thompson R, Dubowitz $H$, et al. Adverse childhood experiences and child health in early adolescence. JAMA Pediatr. 2013; https://doi.org/10. 1001/jamapediatrics.2013.22.

55. Margolin G, Vickerman KA, Oliver PH, Gordis EB. Violence exposure in multiple interpersonal domains: cumulative and differential effects. J Adolesc Health. 2010; https://doi.org/10.1016/j.jadohealth.2010.01.020.

56. Armitage R, Flynn H, Hoffmann R, Vazquez D, Lopez J, Marcus S. Early developmental changes in sleep in infants: the impact of maternal depression. Sleep. 2009;32(5):693-6.

57. Hairston IS, Waxler E, Seng JS, Fezzey AG, Rosenblum KL, Muzik M. The role of infant sleep in intergenerational transmission of trauma. Sleep. 2011; https://doi.org/10.5665/ SLEEP.1282.

58. Wolke D, Lereya ST. Bullying and parasomnias: a longitudinal cohort study. Pediatrics. 2014; https://doi.org/10.1542/peds.2014-1295.

59. Wise LA, Palmer JR, Rothman EF, Childhood RL. abuse and early menarche: findings from the black women's health study. Am J Public Health. 2009; https://doi.org/10.2105/AJPH.2008.149005.

60. Gilbert AL, Bauer NS, Carroll AE, Child DSM. exposure to parental violence and psychological distress associated with delayed milestones. Pediatrics. 2013; https://doi.org/10.1542/peds.2013-1020. 
61. Yang S, Kramer MS. Paternal alcohol consumption, family transition and child development in a former Soviet country. Int J Epidemiol. 2012; https://doi.org/10.1093/ije/dys071.

62. Subramanian SV, Ackerson LK, Subramanyam MA, Wright RJ. Domestic violence is associated with adult and childhood asthma prevalence in India. Int J Epidemiol. 2007; https://doi.org/10.1093/ije/dym007.

63. Gupta RS, Zhang X, Springston EE, et al. The association between community crime and childhood asthma prevalence in Chicago. Ann Allergy Asthma Immunol. 2010; https://doi.org/10.1016/j.anai.2009.11.047.

64. O'Donnell M, Nassar N, Leonard H, et al. Rates and types of hospitalisations for children who have subsequent contact with the child protection system: a population based case-control study. J Epidemiol Community Health. 2010; https://doi.org/10.1136/jech.2009.093393.

65. Voerman JS, Vogel I, de Waart F, et al. Bullying, abuse and family conflict as risk factors for chronic pain among Dutch adolescents. Eur J Pain. 2015; https://doi.org/10.1002/ejp.689.

66. Collin SM, Tilling $\mathrm{K}$, Joinson $\mathrm{C}$, et al. Maternal and childhood psychological factors predict chronic disabling fatigue at age 13 years. J Adolesc Health. 2015; https://doi.org/10.1016/j.jadohealth.2014.09.002.

67. van Tilburg MA, Runyan DK, Zolotor AJ, et al. Unexplained gastrointestinal symptoms after abuse in a prospective study of children at risk for abuse and neglect. Ann Fam Med. 2010; https://doi.org/10.1370/afm.1053.

68. Schmid G, Schreier A, Meyer R, Wolke D. Predictors of crying, feeding and sleeping problems: a prospective study. Child Care Health Dev. 2011; https://doi.org/10.1111/j.1365-2214. 2010.01201.x.

69. Plomin R, Owen MJ, McGuffin P. The genetic basis of complex human behaviors. Science. 1994; https://doi.org/10.1126/science.8209254.

70. Bouchard TJ Jr. Genes, environment, and personality. Science. 1994; https://doi.org/10.1126/science.8209250.

71. Charmandari E, Tsigos C, Chrousos G. Endocrinology of the stress response. Annu Rev Physiol. 2005; https://doi.org/10.1146/annurev.physiol.67.040403. 120816.

72. Habib KE, Gold PW, Chrousos GP. Neuroendocrinology of stress. Endocrinol Metab Clin North Am. 2001; http://dx.doi.org/10.1016/S0889-8529(05)70208-5.

73. Chrousos GP, Gold PW. The concepts of stress and stress system disorders. Overview of physical and behavioral homeostasis. JAMA. 1992; https://doi. org/10.1001/jama.1992. 03480090092034.

74. Tsigos C, Chrousos GP. Hypothalamic-pituitary-adrenal axis, neuroendocrine factors and stress. J Psychosom Res. 2002; http://dx.doi.org/10.1016/S00223999(02)00429-4.

75. Elzinga BM, Roelofs K, Tollenaar MS, Bakvis P, van Pelt J, Diminished SP. cortisol responses to psychosocial stress associated with lifetime adverse events a study among healthy young subjects. Psychoneuroendocrinology. 2008; https://doi.org/10.1016/j.psyneuen.2007.11.004.

76. Gunnar MR, Frenn K, Wewerka SS, Van Ryzin MJ. Moderate versus severe early life stress: associations with stress reactivity and regulation in 10-12year-old children. Psychoneuroendocrinology. 2009; https://doi.org/10.1016/j. psyneuen.2008.08.013.

77. Bethell CD, Newacheck P, Hawes E, Halfon N. Adverse childhood experiences: assessing the impact on health and school engagement and the mitigating role of resilience. Health Aff (Millwood). 2014; https://doi.org/ 10.1377/hlthaff.2014.0914.

78. Sege RD, American Academy A-JL. of Pediatrics Committee on Child Abuse and Neglect, Council on Foster Care, Adoption, and Kinship Care; American Academy of Child and Adolescent Psychiatry Committee on Child Maltreatment and Violence; National Center for Child Traumatic Stress. Clinical considerations related to the behavioral manifestations of child maltreatment. Pediatrics. 2017; https://doi.org/10.1542/peds.2017-0100.

79. Boyce WT, Biological EBJ. sensitivity to context: I. An evolutionarydevelopmental theory of the origins and functions of stress reactivity. Dev Psychopathol. 2005;17(2):271-301.

80. Belsky J, Pluess M. Beyond diathesis stress: differential susceptibility to environmental influences. Psychol Bull. 2009; https://doi.org/10.1037/ a0017376.

81. Garner AS, Shonkoff JP, Siegel BS, et al. Early childhood adversity, toxic stress, and the role of the pediatrician: translating developmental science into lifelong health. Pediatrics. 2012; https://doi.org/10.1542/peds.2011-2662.

82. Traub F, Boynton-Jarrett R. Modifiable resilience factors to childhood adversity for clinical pediatric practice. Pediatrics. 2017; https://doi.org/10. 1542/peds.2016-2569.
83. Asarnow JR, Rozenman M, Wiblin J, Zeltzer L. Integrated medical-behavioral care compared with usual primary care for child and adolescent behavioral health: a meta-analysis. JAMA Pediatr. 2015; https://doi.org/10.1001/ jamapediatrics.2015.1141.

84. Martin A, Barajas RG, Brooks-Gunn J, Hale L. Parenting services may be an opportunity for improving bedtime routines among at-risk preschoolers. Behav Sleep Med. 2011; https://doi.org/10.1080/15402002.2011.606771.

85. Bethell C, Gombojav N, Solloway M, Wissow L. Adverse childhood experiences, resilience and mindfulness-based approaches. common denominator issues for children with emotional, mental, or behavioral problems. Child Adolesc Psychiatr Clin N Am. 2016; https://doi.org/10.1016/j. chc.2015.12.001

86. Nurius PS, Green S, Logan-Greene P, Borja S. Life course pathways of adverse childhood experiences toward adult psychological well-being: A stress process analysis. Child Abuse Negl. 2015; https://doi.org/10.1016/j. chiabu.2015.03.008.

87. Flynn $A B$, Fothergill KE, Wilcox $H C$, et al. Primary care interventions to prevent or treat traumatic stress in childhood: a systematic review. Acad Pediatr. 2015; https://doi.org/10.1016/j.acap.2015.06.012.

88. Hornor G. Childhood trauma exposure and toxic stress: what the PNP needs to know. J Pediatr Health Care. 2015; https://doi.org/10.1016/j. pedhc.2014.09.006.

\section{Submit your next manuscript to BioMed Central and we will help you at every step:}

- We accept pre-submission inquiries

- Our selector tool helps you to find the most relevant journal

- We provide round the clock customer support

- Convenient online submission

- Thorough peer review

- Inclusion in PubMed and all major indexing services

- Maximum visibility for your research

Submit your manuscript at www.biomedcentral.com/submit

) Biomed Central 